\title{
Proximate and Sensory Evaluation of Fortified Fermented Local Meal from Pigeon Pea (CAJANUS CAJAN) and Unripe Plantain
}

\author{
Odion-Owase, E, Oladebeye, A. A. and Olukoya, F. O. \\ Department of Food Technology, Auchi Polytechnic, Auchi
}

\begin{abstract}
A fortified fermented local meal was produced from pigeon pea and unripe plantain. $50 \mathrm{~kg}$ of pigeon pea was subjected to solid state method of fermentation for $72 \mathrm{hrs}$. Samples of meal were produced from fermented pigeon pea and unripe plantain at different ratios and labeled samples A, B and C. sample A had 10\% fermented pigeon pea and $90 \%$ unripe plantain flour, sample B had $20 \%$ fermented pigeon pea and $80 \%$ unripe plantain flour while sample $\mathrm{C}$ had $30 \%$ fermented pigeon pea and $70 \%$ unripe plantain flour. The three samples were subjected to proximate and sensory evaluations. There was significant $\backslash$ difference $(p \leq 0.05)$ in the protein contents of the samples. Sample $\mathrm{C}$ had the highest protein content while sample A had the least. There was no significant difference $(\mathrm{p} \leq 0.05)$ in the moisture, crude fibre, ash contents of the samples. Sample $\mathrm{C}$ had the highest fat and least carbohydrate while sample A had the least fat and highest carbohydrate contents. The sensory evaluation result showed that sample $\mathrm{C}$ was most preferred while sample A was least preferred. However, there was no significant difference $(p \leq 0.05)$ in the sensory parameters of the samples.
\end{abstract}

Keywords: Proximate, Sensory, Parameters, fermentation, Samples.

DOI: $10.7176 /$ FSQM/111-03

Publication date:October $31^{\text {st }} 2021$

\section{Introduction}

Pigeon pea (Cajanus cajan) is a legume crop grown in the tropics and widely consumed in Africa, India and the Caribbean. It contains about $19.6 \%$ protein (Okpala and Mamah, 2001) and therefore serves as an important source of vegetable protein. Pigeon pea contains $20-22 \%$ protein, $1.2 \%$ fat, $65 \%$ carbohydrate and $3.8 \%$ ash (Onweluzo and Nwabugwu, 2009) high levels of cysteine, methionine and lysine (Osagie, 1998) and smaller amount of oligosaccharides (Singh, 1988).

Processing techniques such as boiling, roasting and germination are means of improving the nutritional value of food (Nergiz and Gokgoz, 2007). Fermentation is defined as a bio-processing using microorganism and their enzymes to achieve desirable quality characteristics of food products (Singhanai, 2009). The origin of fermented foods goes back to thousands of years. It is one of the oldest ways of food processing. According to (Lawal, et. al, 2009), fermentation improves food digestibility and nutritional quality.

Plantain (Musa paradisiacal) belongs to the genus Musa in the family of Musaceae. It is a giant perennial herb and cultivated in the many tropic and subtropical countries of the world. It ranks third after yam and cassava for sustainability in Nigeria. It is used as a source of starchy staple food for millions of people in Nigeria. Mature plantain pulp is rich in iron, potassium and vitamin A but low in protein and fat.

\section{Aims and Objectives}

- To produce fortified fermented local meal from pigeon pea and unripe plantain.

- To produce local meal of high nutritional value to solve the problem of malnutrition particularly in children

- To determine the proximate composition of the formulated fortified fermented local meal from pigeon pea and unripe plantain.

- $\quad$ To determine the sensory qualities of the formulated fortified fermented local meal from pigeon pea and unripe plantain.

\section{Materials and Methods}

- Samples collection

- Sample procession prior to use

- Fermentation of pigeon pea using solid state method

- Formulation of fortified fermented local meal.

\section{Proximate Analysis}

The method of AOAC (2016) was used to determine the proximate composition of formulated fortified fermented local meal from pigeon pea and unripe plantain. 


\section{Sensory Evaluation}

Sensory Evaluation was carried out on the formulated local meal. A panel of ten semi-trained panelist were randomly selected. A 9 point hedonic scale was used for the evaluation where I represented, "dislike extremely and 9 like extremely" the texture, taste, colour, aroma and overall acceptability were evaluated (Lawal, et al., 2009).

\section{Results}

Table 1: Proximate composition of local meal from fermented pigeon pea and unripe plantain

\begin{tabular}{|c|c|c|c|c|c|c|}
\hline Sample & $\begin{array}{c}\text { Moisture } \\
\%\end{array}$ & $\begin{array}{c}\text { Ash } \\
\text { \% }\end{array}$ & $\begin{array}{c}\text { Fibre } \\
\%\end{array}$ & $\begin{array}{c}\text { Fat } \\
\%\end{array}$ & $\begin{array}{c}\text { Protein } \\
\% \%\end{array}$ & $\begin{array}{l}\text { CHO } \\
\%\end{array}$ \\
\hline $\mathbf{A}$ & $4.38^{a} \pm 0.01$ & $1.92^{\mathrm{b}} \pm 0.05$ & $3.24^{\mathrm{ab}} \pm 0.02$ & $2.13^{\mathrm{cb}} \pm 0.05$ & $15.72^{\mathrm{da}} \pm 0.01$ & $72.53^{\mathrm{e}} \pm 0.05$ \\
\hline B & $4.39^{a} \pm 0.01$ & $1.96^{\mathrm{b}} \pm 0.05$ & $3.78^{\mathrm{bd}} \pm 0.02$ & $2.26^{\mathrm{cb}} \pm 0.05$ & $17.61^{\mathrm{db}} \pm 0.01$ & $70.10^{\mathrm{eb}} \pm 0.05$ \\
\hline $\mathbf{C}$ & $4.36^{\mathrm{a}} \pm 0.01$ & $1.98^{b} \pm 0.05$ & $3.81^{\mathrm{c}} \pm 0.02$ & $2.68^{\mathrm{d}} \pm 0.05$ & $19.24 d^{c} \pm 0.01$ & $67.93^{\mathrm{ed}} \pm 0.05$ \\
\hline
\end{tabular}

Means with the same superscript down the column are not significantly different $(\mathrm{p} \leq 0.05)$.

Note: $A=10 \%$ fermented pigeon pea and $90 \%$ unripe plantain

$\mathrm{B}=20 \%$ fermented pigeon pea and $80 \%$ unripe plantain

$\mathrm{C}=30 \%$ fermented pigeon pea and $70 \%$ unripe plantain

Table 2: Means for sensory evaluation of local meal from fermented pigeon pea and unripe plantain

\begin{tabular}{|l|l|l|l|l|l|}
\hline Sample & Texture & Taste & Colour & Aroma & $\begin{array}{l}\text { General } \\
\text { Acceptability }\end{array}$ \\
\hline A & $7.30^{\mathrm{a}} \pm 0.23$ & $6.81^{\mathrm{ab}} \pm 0.01$ & $6.24^{\mathrm{b}} \pm 0.02$ & $8.52^{\mathrm{bc}} \pm 0.01$ & $7.36^{\mathrm{c}} \pm 0.05$ \\
\hline B & $7.36^{\mathrm{a}} \pm 0.21$ & $6.98^{\mathrm{ac}} \pm 0.01$ & $6.26^{\mathrm{b}} \pm 0.02$ & $8.56^{\mathrm{bc}} \pm 0.02$ & $8.52^{\mathrm{cb}} \pm 0.05$ \\
\hline $\mathbf{C}$ & $7.38^{\mathrm{a}} \pm 0.2$ & $7.41^{\mathrm{ad}} \pm 0.01$ & $6.28^{\mathrm{b}} \pm 0.02$ & $8.57^{\mathrm{bc}} \pm 0.01$ & $8.81^{\mathrm{cd}} \pm 0.05$ \\
\hline
\end{tabular}

Means with the same superscript down the column are not significantly different $(\mathrm{p} \leq 0.05)$

Note: $A=10 \%$ fermented pigeon pea and $90 \%$ unripe plantain

$\mathrm{B}=20 \%$ fermented pigeon pea and $80 \%$ unripe plantain

$\mathrm{C}=30 \%$ fermented pigeon pea and $70 \%$ unripe plantain

\section{Discussion}

The result of the proximate composition showed that there was no significant differences $(p \leq 0.05)$ in the moisture and ash contents of the samples. The moisture contents of the samples were low which is very significant since dry or low moisture increases shelf life of food (Ihekoronye and Ngoddy, 1985) high moisture content may encourage microbial proliferation and food spoilage (Ajayi and Oyetayo, 2009). There were significant difference $(\mathrm{p} \leq 0.05)$ in the crude fibre, fat protein and carbohydrate content of the samples. Sample $\mathrm{C}$ had the highest protein value and the least carbohydrate value. Sample A had the least protein value and the highest carbohydrate value. This can be attributed to the percentage of pigeon pea added to the samples. The result obtained in the sensory evaluation showed that the organoleptic ratings of the formulated local meal. All samples were accepted by the panelists considering the sensory parameters. There was no significant difference $(p \leq 0.05)$ in the texture, colour and aroma of all the samples, however, there were significant different $(p \leq 0.05)$ in the taste and general acceptability of all the samples. Generally, sample $\mathrm{C}$ was most preferred by the panelist while sample A was least preferred by the panelist.

\section{Conclusion}

The formulated local meal from fermented pigeon pea and unripe plantain was rich in protein and carbohydrate. The formulated local meal had high nutritional value. Also, all the formulated samples were accepted by the panelist considering the sensory parameters

\section{Recommendation}

The formulated local meal from fermented pigeon pea and unripe plantain can serve as composite flour which can be used for domestic purpose. It can also be used as weaning food to solve the problem of malnutrition in children.

\section{Acknowledgement}

The authors are thankful to TETFUND for providing this institutional based Research (IBR) grant to facilitating this research. This indeed has given us the opportunity to contribute our quota to the nation building in terms of food production and development. 


\section{References}

AOAC, (2016). Official method of analysis. Association of official analytical chemists. $22^{\text {nd }}$ edition. Washington DC. PP. $35-60$

Ajayi .O.B and Oyetayo, F.I. (2009) Potentials of kerstingiella Geocarpa as health food: Journal of Medicinal Food 12 (1) 184-187

Fawole, M. O. \& Oso, B. A. (2004). Characterization of bacteria: Laboratory Manual of Microbiology. $3^{\text {rd }}$ Edition. Spectrum Book Limited, Ibadan. Nigeria PP $24-26$

Ihekoronye, A. I. \& Ngoddy, P. O. (1985). Integrated food science and technology for the tropics $1^{\text {st }}$ edition. Macmillan Publishers ltd

Lawal, A. K.; Oyedoyin, .O.B and Olatunji, .O. (2009). Fate of Pathogenic bacteria during the fermentation of cereal porridge (Ogi). A wearing Food formula. Nigerian Food Journal 27(1) 19 - 24

Nergiz, C. \& Gokgoz, M. (2007). Effects of traditional cooking methods on some ant nutrients and invitro protein digestibility of vean varieties (Phaseolus vulgancies ) grown in Turkey. International Journal Of Food Science. Tech : 42 (7) 868-873

Okpala, L.C. \& Mamah, E.N. (2001). Functional properties of raw and processed pigeon peas (Cajanus cajan) flour. International Journal of Food Sciences and Nutrition (52) 343-346

Onweluzo, J.C. \& Nwabugwu, C.C. (2009). Nutrient and anti-nutrient composition of Condiments produced from some fermented underutilized legumes. Journal of Food Biochemistry 30 (5)576-588

Osagie, A.U (1998). Anti nutritional factors in AU Osagie .O U Eked (ed). Nutritional Quality of Plant Foods PP -53-83. Published by post Harvest Research unit department of biochemistry. University of Benin Nigeria.

Singh, U. (1988). Anti-nutritional factors of chickpea and pigeon pea and their removal by processing plants foods. Human Nutrition 35, 339-35

Singhania, R.R.; Patel A. K.; Soccol, C. R. \& Pardey, A. (2209) Recent advanced in solid state fermentation in biochemistry. English Journal Vol .44 (1) 13-18 